\title{
Understanding Basic English Users' Classroom Interaction: A Case Study
}

\author{
Comprendiendo la interacción en clase de los usuarios básicos \\ de inglés: Un estudio de caso
}

\author{
Ximena Rocío Contreras-Espinosa ${ }^{1}$ \\ Karen Michell Villamizar-Mantilla ${ }^{2}$
}

\begin{abstract}
This qualitative case study seeks to understand the importance of interaction in an A1-English language course at a public university in Colombia. Data were collected through six non-participant observations and four semi-structured interviews. Data were organized and analyzed by using MAXQDA software. These instruments provided enough information of the participants' perspectives about the importance of interaction when learning a new language. With these instruments, it was also possible to find the types of interaction that occurred between the participating teacher and students in the observed foreign language classroom. The findings reveal five different interaction patterns that emerged depending on its purpose, who started them, when they occurred, and how they were given. ${ }^{3}$

Keywords: case study, classroom interaction, learning strategy, interaction patterns

1 She holds a BA in languages, English-French from the University of Pamplona, Colombia.

One of her research interests is to understand the interaction patterns that emerged in foreign language classroom.

ximenacont22@gmail.com

ORCID ID: https://orcid.org/0000-0002-4044-1228

2 She holds a BA in languages, English-French from the University of Pamplona, Colombia.

One of her research interests is to understand the interaction patterns that emerged in foreign language classroom.

kmmantilla2408@gmail.com

ORCID ID: https://orcid.org/0000-0002-2343-0287

Received: April 13th, 2020. Accepted: May 30th, 2020.

This article is licensed under a Creative Commons Attribution-Non-Commercial-No-Derivatives 4.0 International License. License Deed can be consulted at https://creativecommons.org/licenses/by-nc-nd/4.0.

3 The authors express their appreciation of a review made by David Punter, freelance ESL/EFL teacher.
\end{abstract}

HOW Journal 


\section{Resumen}

Este caso de estudio cualitativo busca comprender la importancia de la interacción en un curso de inglés A1 en una universidad pública de Colombia. Los datos se recopilaron por medio de seis observaciones de no participantes y cuatro entrevistas semiestructuradas. Los datos se organizaron y analizaron con el software MAXQDA. Estos instrumentos proporcionaron suficiente información de las perspectivas de los participantes sobre la importancia de la interacción al aprender un nuevo idioma. Con estos instrumentos, fue también posible encontrar los tipos de interacción que ocurrieron entre el docente participante y los estudiantes en el aula de lengua extranjera observada. Los hallazgos revelan que surgieron cinco patrones de interacción diferentes dependiendo de su propósito, quién los inició, cuándo ocurrieron y cómo se dieron.

Palabras clave: estudio de caso, interacción, estrategia de aprendizaje, patrones interaccionales

\section{Introduction}

Learning a foreign language involves mastering four basic language skills: listening, speaking, reading, and writing. The Common European Framework of Reference for Languages (CEFR) categorizes the ability to produce and communicate ideas to others into six different levels as a guide to learning a new language by keeping in mind general concepts and abilities, ranging from a basic user to an advanced user (A1, A2, B1, B2, C1, and C2). In this way, learning a language requires the development of the competencies described by each level of proficiency in order to use the language adequately.

In a foreign language classroom, interaction varies depending on the objective of developing skills like memory, reasoning, attention, and language. Those activities create a mediation process in which students could have a social reflection from an individual reflection. Notably, language is a crucial aspect for cognitive development since people are cognitive agents in the environment where they live.

In this way, foreign language teaching should include different strategies that engage learners in active interaction throughout the learning process. Nunan (1989) states that, "Language is now generally seen as a dynamic resource for the creation of meaning" (p. 12). Every activity completed in a foreign language classroom should foster meaningful target language use and teacher-student dynamic interaction. The way we interact with our classmates and teachers plays a tremendous role in our personal learning experience of foreign languages. This type of interaction could be closely related to Walsh's concept of Classroom Interactional Competence (CIC), which is defined as, '[ $t$ teachers' and learners' ability to use interaction as a tool for mediating and assisting learning' (Walsh, 2013, p. 158). We have come to understand that this competence has helped researchers improve their language skills, exchange personal ideas, thoughts and beliefs, and overcome common pronunciation mistakes and language use difficulties. Researchers also benefited from this 
Ximena Rocío Contreras-Espinosa

Karen Michell Villamizar-Mantilla

reciprocal learning experience during class activities in which they acquired and exchanged knowledge with their classmates and teachers.

In the Bachelors of Arts in Languages program in which this study took place, speaking skills are considered as one of the most useful and important skills of a language because these are related to the transmission and reception of information. As foreign language (FL) learners, we experienced a series of drawbacks linked to oral interaction in the classroom, such as lack of time to complete class activities, use of poor strategies, and low levels of participation. When performing a role play, the peers' pressure and time constraints did not let us use the language in an appropriate way due to the stance/conviction that completing the task was more important than the use of the language. Moreover, those drawbacks were noticed in group activities as debates in which not all the students participated because of lack of security and the fear of being judged by teachers and peers. Given those experiences, we became aware of the difficulties a learner may face in expressing their ideas in ordinary class activities.

Rivers (1987) explained the role of interaction while learning a language saying that, through interaction, students can increase their language store as they listen to or read authentic linguistic material, or even when they absorb output from their fellow students in discussions, skits, joint problem-solving tasks, or dialogue journals. In interaction, students can use all they possess of the language - all they have learned or casually absorbed - in real life exchanges (Rivers, 1987, as cited in Trong Tuan \& Kim Nhu, 2010, pp. 4-5). This means that the role of interaction goes beyond communicating with others; the interaction in class helps students to improve their language skills putting in practice the language in different ways.

Several studies about the importance and analysis of interaction have been carried out in different educational contexts around the world in order to understand how participants are involved in spoken interactions and tasks in the target language. Nóbrega's (2008) and Kuśnierek's studies (2015), among others, stated that interaction in the FL classroom is important because it helps students to communicate their ideas and thoughts by using the target language as well as to create a better atmosphere in the classroom. In Colombia, some studies have been carried out about it in high school contexts, for example Gómez (2012), 32 Gutierrez (2005), Hernandez (2013), Ochoa et al. (2016), Parga Herrera (2009), Bohórquez et al. (2011), Rosado-Mendinueta (2012) and Lucero Babativa (2015); those studies reflect on the necessity of understanding the role of interaction in a foreign language classroom.

Consequently, this study focused on understanding the importance of interaction in Basic English Foreign Languages courses at a public university of Colombia. Taking into account that these courses look for developing learners to reach an A2-level of proficiency in English, learners develop an understanding of the basic structures of the language. The 
learners should be able to express themselves by giving basic personal and family information, and to describe routines using simple and direct exchange of information. This course is guided by a textbook of an A2-English level of proficiency, which includes an introductory section of new vocabulary related to the topics, then an explanation of the grammatical tenses, followed by activities such as reading passages, listening exercises, writing production, and a communicative task. The total amount of hours per academic semester is 128 , or seven hours weekly.

The data were collected over four months in a course of Basic English language level through class activities and students' perspectives. This study attempted to answer this research question: What type of student-student and student-teacher interaction takes place in a foreign language class?

\section{Literature Review}

Language classroom interaction is the set of communicative events (conversations or exchanges) that teachers and learners co-construct from the context to promote language learning and/or language use (Ellis, 1994, as cited in Lucero, 2015, p. 92). Johnson (1994) establishes that teacher-learner interaction occurs when the teacher controls the content, use of language, and learners' participation in class (as cited in Lucero, 2015, p. 93). In learnerto-learner interaction, the learners use the target language with one another in classroom activities" (as cited in Lucero, 2015, p. 93). Concerning learner-teacher interaction, some say "...this type of classroom interaction occurs when a learner volunteers to provide content during a discussion opened for using and/or learning the target language. In the learnerteacher interaction, the learners provide the content; thus, they create the opportunities to use the language in class" (Richards and Lockhart, 1994, as cited in Lucero, 2015, p. 93).

Through interaction students can increase their language store as they listen to or read authentic linguistic material, or even the output of their fellow students in discussions, skits, joint problem-solving tasks, or dialogue journals. In interaction, students "can use all they possess of the language - all they have learned or casually absorbed - in real life exchanges" (Rivers, 1987, as cited in Trong Tuan \& Kim Nhu, 2010, pp. 4-5). These two definitions describe all the interaction processes from physical actions to how interaction helps students in the development of students' language skills.

Oxford (1990, p. 8) defines strategies as "specific actions taken by learners to make learning easier, faster, more enjoyable, more self-directed, more effective, and more transferable to new situations. As researchers, we realized that Oxford's definition neatly matches the purpose of this study given that she showed strategies as a vehicle for learning 
Ximena Rocío Contreras-Espinosa

Karen Michell Villamizar-Mantilla

in which not only students take advantage but also teachers; therefore, making the learning process better.

With regard to prior studies, we classified them into two groups: Classroom interaction and learning strategies in a foreign language classroom. The first group explains the significance of student-student and student-teacher interaction (see Van Lier, 1996, to know what each of these types of interaction means). Parga Herrera's (2009) action research revealed that verbal and non-verbal strategies are important to improve oral interactions among students. She also found that teachers can achieve a better social classroom atmosphere for learning, including cooperative learning in their class, while improving their performance in the EFL course. Similarly, Nóbrega (2008) found that oral interaction engages teachers and students in learning language processes in which students and teachers exchange and understand the information. Similarly, Kuśnierek (2015) concluded in her study that oral interaction activities not only provide students with the ability to communicate their thoughts and ideas, but also with the ability to exchange information with others highlighting the importance of transmission and reception of information. Gomez (2012) stated in her study that this exchange of information could be done by using the mother tongue. She concluded that not only the use of the mother tongue is fundamental for students to understand the class topic and communicate with their teacher and students, but also to participate in class activities. Also, Lucero (2012) found two types of interaction patterns given in class between the teacher and the students: asking about content and adding content. These interactional patterns are given by means of the speech acts that emerge in classroom interaction when there is a need for communication by the actors. Finally, Ochoa et al.'s (2016) study revealed that communicative activities are motivating for both students and teachers. They found that students feel highly motivated when participating in communicative activities because these enhance their fluency. They were also confident when they helped each other during interaction in activities.

The second group of studies describes the role of learning strategies in a foreign language classroom. Hardank (2013) explained the definition of strategies by using different authors as Oxford (1990). Some researchers have guided studies in order to analyze how the use of interactive learning strategies help improve student's language skills in EFL contexts. For example, Henriquez et al. (2017) conducted a quasi-experimental investigation in which they found that the use of social strategies like working in groups or presenting a topic, among others, encouraged students to collaborate and helped to improve students' speaking skills at the same time. Similarly, Cruz Rondón \& Velasco Vera (2016) concluded in their case study that the way the teacher implemented a pedagogical intervention integrating the four language skills promoted interactive learning among students. Darancik (2018) revealed that the language skills that students want to develop the most are speaking skills because these allow them to exchange their ideas and information in a better way. Likewise, 
Gutiérrez Gutiérrez (2005) found that carrying out interactive and communicative tasks helped students develop speaking skills that allowed them to interact in different situations. Similarly, Soraya (2017) argued that role play was an effective strategy that urged students to speak directly in the target language and face real situations. Moreover, they considered that role play developed communicative competence that placed students as active learners and improved their participation in the class. Besides, Lafont Mendoza (2007) concluded that activities as interactive and group tasks eased students' oral participation in class while others limited it, provoking anxiety in students. She also found that self-esteem, anxiety, empathy, and relationships among students were factors that affected students' oral production.

Other authors who focused on the task-based approach obtained similar findings: Hernandez (2013) found that Task-Based Learning used communicative learning strategies to enhance students to develop their oral interaction skills and allowed them to become more confident and motivated to learn the language. Similarly, Gonzalez Humanez and Arias (2009) found that Task-Based Learning activities not only helped to encourage students' participation in class but also helped them to improve the quality of oral interaction as well as to interact meaningfully and spontaneously. Even when those strategies were used as strategies to improve the students' interaction, Perneth Parra (2012) revealed that they should not be repetitive because they may lose their effectiveness in the classroom since they may become monotonous.

Finally, Lucero (2015) wrote about classroom interaction taking into account three different research works conducted by him; in the first work, he found that the mother language was used for students in order to supply communication needs, and to understand meanings and grammatical structures. With regard to his second work, it revealed that the interaction in the classroom was given among teacher and learners in two main situations to ask about content and add content. Finally, in his third work (Lucero, 2011), he found an interaction pattern that he named the request-provision-acknowledgement (RPA) sequence; this interaction pattern was co-constructed by teachers and learners when the latter did not know how to express an idea in English and asked the former for answers using the L1, creating a negotiation of meaning among them.

\section{Research Methodology}

The study presented in this article is of a naturalistic inquiry because it took place "in real-world settings and the researcher [did] not attempt to manipulate the phenomenon of interest..." (Patton, 2002, p. 39). In other words, we, the researchers and authors of this article, observed a group of foreign language learners interacting with their teacher in an ordinary English language classroom. We followed a case study methodology because we were interested in conducting an in-depth understanding on the importance of interaction 
as a means of improving English language basic users' speaking skills. Creswell (2007) stated that "a case study is an in-depth exploration of a bounded system based on extensive data collection" (p. 14). Thus, this study is an attempt to describe second-semester students' activities to evaluate their progress in the learning of English. In this study, the unit of analysis is represented, in terms of space, by an English language second-semester course of the Bachelor in Arts in Languages program at a public university of Colombia. In terms of time, this study was conducted during the first academic semester in 2019.

We were interested in working with students at the English language basic-user level because we considered that they were starting to develop their language and communicative skills as English language learners. Moreover, in this stage of the language course, students were more exposed to work in different communicative and interactive activities that allowed them to improve their English language skills. Participants were a teacher of English as a foreign language and a group of 22 learners at an A2 English language proficiency level. Two key informants were voluntarily selected from the learners group to be interviewed.

Data were gathered through six non-participant observations and four interviews with open-ended questions. According to Creswell (2007), "observations, interviews, audiovisual material, documents and reports [comprise] a case description and case-based themes. For example, several programs (a multi-site study) or a single program ([an inside] study) may be selected for study" (p. 73). The non-participant observations helped to investigate this issue without interfering in the participants' interactions. In addition, four semi-structured interviews with open-ended questions allowed the participants to share their perspectives in their own words by giving a more detailed experience in order to explain their ideas.

\section{Ethical Considerations}

Ethics are considered in research as the legal and moral considerations that are taken into account when an investigation is conducted. That is why we considered various ethical issues at different levels of this process to protect the participants' rights by following rigorous procedures such as the use of pseudonyms, letters of consent of participants of the study, and letters of permission to the participants. With regard to the use of pseudonyms, this allowed participants to protect their identity. Throughout the data collection, each participant selected a nickname not associated with him or her. The letter of consent and the letter of permission provided a detailed description of the procedures of the investigation. This way, the participants knew the role they would play and their responsibilities. In addition, we explained that they could drop out the project if they considered that the research study interfered in any way with their personal or academic development. We also stated that noneconomic rewards were given for participating in this study and that no risks or secondary 
effects were associated with the participation in this research. Finally, the data were protected and saved in a password-protected document that only we, as the researchers, had access to.

\section{Findings}

Data were analyzed following Hatch's (2002) interpretative analysis, i.e. "Interpretation is about giving meaning to the data. It is about making sense of social situations by generating explanations for what's going on within them" (p. 180). In doing so, we interpreted the data gathered in light of the research question. This interpretation allowed us to identify the types of student-student and student-teacher interactions that took place in the observed classroom. These interactions were classified taking into account the six non-participant classroom observations done during the gathering information process. The classified interactions were the most predominant ones in the learning atmosphere. Besides, we used MAXQDA software to classify the interactions from codes and sub-codes. Consequently, five different interaction types were identified: teacher-students, teacher-student, student-teacher, students-teacher, and students-students.

\section{Teacher-Students' Interaction}

It describes the way the teacher addressed all the students at once. This type of interaction allowed the teacher to give instructions, explain topics and activities, and provide them with new vocabulary in English. With regard to giving instructions, the teacher provided students with specific directions for them to complete each activity in class. For example, specific instructions on how they had to do each activity. During the third classroom observation, the teacher decided to start the class by explaining to the students how a quiz would be conducted. The quiz consisted of presenting orally and voluntarily the passive voice in English in groups of three people. This example shows the aspects that the teacher took into account when giving instructions, such as: the activity that was to be developed, the topic that was going to be assessed, the number of participants, and the way they needed to present it. Another example was during the fourth classroom observation, the teacher introduced new vocabulary in English related to slang and urban language by saying words/phrases out loud and letting students guess the words' spelling and their meaning; after a couple of minutes, the teacher wrote all the vocabulary down on the board and explained each lexical item by using sentences as an example of how and when to use it.

Teacher-students' interaction was also reflected while explaining a topic. The teacher interacted with all the students while introducing a new grammatical topic of English from the textbook. In the second classroom observation, for instance, the teacher explained how, why, and when to use countable and uncountable nouns in English. He also gave some examples. Then, the students completed the different textbook activities. Finally, the teacher 
Ximena Rocío Contreras-Espinosa

Karen Michell Villamizar-Mantilla

asked the students to prepare an oral report in English about a typical Colombian dish by using countable and uncountable nouns and explaining the cooking process. This interaction shows the way the teacher introduced and explained a new grammar topic by including examples to facilitate for students a better understanding.

Teacher-students' interaction also occurred while introducing new vocabulary in English. The teacher included new terms or expressions not only related to more colloquial words/ expressions but also to academic language in English. For example, the teacher dictated the words to the students to check their listening skills and comprehension in English and to assess their vocabulary. That vocabulary was used in oral activities and some quizzes during each term. The teacher stated that he would give the new vocabulary composed of five academic expressions and five slang expressions. He started to dictate the words one by one. He repeated each word twice while he was moving around the classroom to check students' written spelling of the dictated words. Finally, he wrote the words down on the board and explained their meaning by using several examples. The teacher assessed the use of these words during the oral exam of each term.

In the interviews, the participants in this current study stated that the methodology that the teacher used when introducing the new vocabulary was difficult. At the beginning of the course, the teacher talked rapidly in English and they did not understand what he was saying. However, they tried to guess the word or expression that the teacher wanted them to learn. This type of interaction helped them improve their target language skills of listening, speaking, and writing.

We realized that teacher-students' interaction was frequently used in the development of the class. Even though there were some changes in the topics explained, the pattern was almost the same during each classroom observation: The teacher gives instructions, explanations, and vocabulary of the class, while the students listen attentively and do as instructed. No further exchange of information occurs: the teacher talks and the students do as instructed.

\section{Teacher-Student Interaction}

This second type of interaction happens when the teacher initiates an interaction by addressing only one student in particular. This interaction gave the addressed student the opportunity to use English, and the teacher to assess him or her. In doing so, the teacher asked the one particular student direct questions for him or her to use the learned vocabulary in English. We realized that, since the first classroom observation, the teacher orally asked only one student questions such as "how is your day?" or "what do you think about the weather?" Sometimes, the student who had been asked did not know how to answer. Therefore, the 
teacher asked their peers for help. After that, the addressed student was supposed to have an idea about what had been asked and what she or he was able to answer.

In this type of interaction, most of the interviewed students expressed that, at the beginning of the course, they did not understand the questions that the teacher asked because of the teacher's higher English language proficiency level. However, they considered it to be a good strategy because they were losing their fear of listening to and using English. At the end of the course, they felt that their oral production had improved.

Teacher-student interaction was also reflected while the teacher was checking one particular student's English language level of speaking. To do so, the teacher asked a student open questions about random topics. This way the student had the opportunity to speak and express his or her ideas. After that, the teacher provided the student with feedback about the vocabulary used, pronunciation of the words, grammar structure, or English language command. For instance in one of the class observations, teacher asked one student what a research task was, and the student gave his own concept about research, then the teacher gave him feedback and he gave a complete meaning about what research was; another example was noticed when the teacher asked one student the meaning of jet lag, given that they were reading about trips; the student was in shock and she could just say that she did not know, then he explain the meaning of the word and told the student not to be afraid of answering. The teacher usually repeated the student's mispronounced words or incorrect grammatical structures. Then, he asked his students in class to reflect on whether or not it was correct. Finally, he gave them the correct pronunciation or appropriate sentence organization.

At other times, the teacher interacted with a particular student through written notes in English. According to the participants, after finishing the oral exam, the teacher gave them a sheet of paper on which he had highlighted the mistakes they had made in the activity. Typical mistakes included commonly mispronounced words, misspelled words, and misused sentence structures. It was common when a student made a mistake that the teacher provided the correction of the mistake in a written way. This written exchange allowed the students to correct their language mistakes with the aim of improving their English language proficiency little by little. The teacher feels that this way of correcting students' mistakes ensures that they do not ingrain mistakes in their memory. Unfortunately, this type of teacher-student interaction was not frequently used by the teacher during a lesson due to time constraints.

\section{Student-Teacher Interaction}

This third type of interaction describes when only one student interacts with the teacher during the classroom activities of a lesson. Here, different from the previous type of interaction, only one student starts interacting with the teacher because the student needs the teacher's help to go on with the classroom activity. In this case, the student perhaps did 
Ximena Rocío Contreras-Espinosa

Karen Michell Villamizar-Mantilla

not know how to express an idea in English, or the student wanted to know the meaning of a word. In both scenarios, the student received the teacher's help while being favored by having the opportunity to express his or her ideas and to deduce how to pronounce the word or its meaning.

The student-teacher interaction allows the teacher to answer all questions that the students ask. For example, in observation number six, one student did not understand the meaning of the word "lingua franca"; that word was necessary to understand the topic of the text given for the lesson. The teacher explained its meaning by using examples; he gave the student a little explanation of the word. Another example of this interaction was evident in the first observation. In that class, the student had to perform and write a role play with the peers; one student was unsure about how she could say "deja de molestar". After being asked by this student, the teacher told her that she could use verbs as "to annoy, to bother, or to disturb" plus various examples by using these verbs. In the interviews, the students and the teacher agreed that this type of interaction fostered a better class atmosphere. Most of the time, this interaction was given when the students prepared an oral or written report.

\section{Students-Teacher Interaction}

This fourth type of interaction describes the interaction of the whole or a small group of students with the teacher during a classroom activity. It took place when one student asked the teacher, on behalf of all his or her classmates, to clarify doubts about the class activity, or to talk about classroom situations. An example of clarifying doubts happened throughout the development of the observed lessons when various students did not understand how to complete a specific activity; then, one of the students asked the teacher how to proceed. For instance, during the second observed session, the teacher asked the students to write a role play in English by using the auxiliary will or the phrase going to to talk about future plans. They did not understand how to complete it and which vocabulary they had to use. Then, one of the students asked the teacher to explain it again. Then, the teacher provided more details on how to complete the activity. The teacher said that they had to work in pairs or groups of three. He also added that they needed to use the vocabulary of unit six. This time, it made it clearer for the students to fully complete the task.

The students-teacher interaction also happens when the students talk to the teacher about some classroom issues. Sometimes, they interacted in Spanish to have a better explanation of the situation. In the fourth class, for instance, we realized that they spent one hour talking about the performance and the logistics for a cultural English language event. That day, they agreed on different roles and responsibilities to guarantee an outstanding presentation. The teacher and the students started talking about how to allocate roles and responsibilities. At the end, each student had a specific task to accomplish. 
Another instance that exemplifies this students-teacher interaction was when the teacher gave them their grades. The students asked the teacher how he had obtained the grades and which aspects he had taken into account when deciding on them. First, the teacher gave them the grades as a group. After that a student asked him about the percentage of each language skill evaluated on the exam. Second, the students asked the teacher specific questions about the aspects that he had taken into account for assessing them.

\section{Students-Students Interaction}

Finally, this type of interaction occurred at two levels: individual level (student-student) and group level (students-students). This interaction describes the oral exchanges among students in the classroom. Both levels of interaction commonly occurred when the students worked in groups, when they needed to ask for their partner's help or when they did not understand the teacher's instructions. During all sessions observed, we realized that the teacher frequently proposed group activities that allowed the students to communicate with one or more of their classmates in English. The group-level interaction occurred not only with the members of the work group but also with members of other groups. In the second classroom observation, for example, they were divided into six groups dispersed around the classroom. Most of the groups were talking to each other. They attempted to practice a role play and to look for vocabulary and ideas in their textbooks. Member of different groups gave expressions and ideas to complete the role play. The individual level happens when students interacted in pairs, one with the other. For example, when a student did not know about a topic or did not know how to pronounce a word in English. In the interviews, the students stated that this type of pair interaction allowed them to engage in cooperative work and to learn from each other.

This students-students interaction was frequently done through verbal and nonverbal language. The students not only communicated with each other by using verbal utterances but also some facial gestures, body language, and even imitation according to the activity given such as worksheets, oral presentations, and exams. In the case of oral presentation and oral exams, they were done with the purpose of evaluating each student's language skill and the ability of communicating using the target language.

\section{Conclusions and Discussion}

Carrying out a naturalistic inquiry allowed us to better understand the importance of interaction in an English as a foreign language classroom mediated by five types of classroom interactions. 
Ximena Rocío Contreras-Espinosa

Karen Michell Villamizar-Mantilla

Mainly, we conclude that, in a foreign language classroom, there are five interaction patterns that emerge from the context depending on its purpose, who started it, when it occurred, and how it was given. Similar to Lucero's (2015) findings, "a language classroom interaction is composed of varied interaction patterns that the teacher and the learners create, co-construct, and then maintain, all in line with the particular interactional context and the established conventions of the class" (p. 109). These interaction patterns were teacherstudent, teacher-students, student-teacher, and students-students. These were intrinsically connected as one complemented the other for the development of the students' speaking skills. These patterns occurred during one or several stages of the session in progress.

Interacting with other people is an ability learned since childhood and started with the social environment that surrounds the individual by giving information about how to communicate with others with a purpose. Interaction favored the development of the language skills in students while working in a cooperative learning manner in which they learned from their classmates and the teacher. Van Lier (1988, as cited in Hermanto, 2005, p. 145) stated that interaction is essential for language learning which occurs in and through participation in speech events; that is, talking to others, or making conversation.

Language classroom interaction is defined as the set of communicative events (conversations or exchanges) that the teacher and learners co-construct from the context to promote language learning and/or language use (Ellis, 1994, as cited in Lucero, 2015, p. 92). The promotion of the language is done through activities carried out during the lessons as communicative tasks in which students are involved in working with their partners by interacting through verbal and non-verbal language in real-life time and a natural context. This process is very similar in a foreign language classroom: each individual is surrounded by an environment that facilitates the use of the foreign language for communicating their ideas, beliefs, and experiences, among others. Language learners need to use, explore, and adapt their language skills to the current linguistics needs and input. That is why different types of classroom interaction, according to their purposes, emerge. These have been organized and classified, highlighting their most relevant and common aspects such as the time and place each one of them took place.

Finally, classroom interaction allowed the participants to communicate their own opinions, beliefs, thoughts, and ideas with their classmates or teachers through their language learning process in class.

\section{References}

Bohórquez-Suárez, I., Gómez-Sará, M., Medina-Mosquera, S. (2011). Pair Negotiation when developing English speaking tasks. HOW Journal, 18(1), 43-57. 
Creswell, J. W. (2007). Qualitative inquiry \& research design: Choosing among five approaches. Sage Publications.

Cruz Rondón, E. J., \& Velasco Vera, L. F. (2016). Understanding the role of teaching materials in a beginners' level English as a foreign language course: A case study. Profile: Issues in Teachers' Professional Development 18(2), 125-137. https://doi.org/10.15446/profile.v18n2.52813

Daranc1k, Y. (2018). Students' viens on language skills in foreign language teaching. Published by Canadian Center of Science and Education. https://doi.org/10.5539/ies.v11n7p166

Gómez, C. (2012). Language learners' identities in EFL settings: Resistance and power through discourse. Colombian Applied Linguistics Journal, 14(1), 60-76.

Gutiérrez Gutiérrez, D. (2005). Developing oral skills through communicative and interactive tasks. Profile: Issues in Teachers` Professional Development, 6(1), 83-96.

González Humanez, L. E., \& Arias, N. (2009). Enhancing oral interaction in English as a Foreign language through task-based learning activities. Latin American Journal of Content \& Language Integrated Learning, 2(2), 1-9.

Hardank, A. A. (2013). Learning languages strategies: A general overview. Social and Behavioral Sciences, 106, 1712-1726.

Hatch, J. A. (2002). Doing qualitative research in education settings. State University of New York Press.

Henríquez, T. K., Von Jhonn, H. I., Peña, V. H., \& Llanquileo, E. A. (2017). The effects of memory and social strategies on oral production. Colombian Applied Linguistics Journal, 19(2), 209-218. https://doi.org/10.14483/22487085.10535

Hermanto, H. (2015). Understanding teacher talk to support students' communicative competence. Jurnal Sosial Humaniora, 8(2), 143-159.

Hernandez, I. (2013). Enhancing oral interaction skills in undergraduate students through task- based language learning [Unpublished Master's dissertation]. Universidad Libre.

Kuśnierek, A. (2015). Developing students' speaking skills through role-play. Teacher Training College in Leszno, Poland. World Scientific News, 7, 73-111.

Lafont Mendoza, L. (2007). Study of factors that affect oral participation in the students of $6^{\text {th }}$ grade at Maria Auxiliadora School in Sahagún Córdoba [Unpublished Master's dissertation]. Universidad del Norte.

Lucero, E. (2011). Code-switching to know a TL equivalent of an L1 word: Request-ProvisionAcknowledgement (RPA) sequence. HOW Journal, 18(1), 58-72.

Lucero, E. (2012). Asking about content and adding content: two patterns of classroom interaction. Colombian Applied Linguistics Journal, 14(1), 28 - 44. https://doi.org/10.14483/22487085.3811

Lucero, E. (2015). Doing research on classroom interaction: Approaches, studies, and reasons. In W. Escobar Alméciga \& H. Castañeda-Peña (Eds.), Discourse analysis applied to English language teaching in Colombian contexts (pp. 83-113). Universidad El Bosque. 
Ximena Rocío Contreras-Espinosa

Karen Michell Villamizar-Mantilla

Nóbrega, D. G. A. (2008). Oral interaction and its implication in the learning and teaching process in EFL. Revista Eletrônica de Divulgação Científica em Lingua portuguesa, Lingüistica e Literatura, 4(8), $1-7$.

Nunan, D. (1989). Designing tasks for the communicative classroom. Cambridge University Press.

Ochoa, C., Cabrera, P., Quiñónez, A., Castillo, L., \& González, P. (2016). The effect of communicative activities on EFL learners' motivation: A Case of students in the Amazon region of Ecuador. Colombian Applied Linguistics Journal, 18(2), 39-48. https://doi.org/10.14483/calj. v18n2.10018

Oxford, R. L. (1990). Language learning strategies: What every teacher should know. Newbury House.

Patton, M. Q. (2002). Qualitative research \& evaluation methods. Sage Publications.

Parga Herrera, F. (2009). Cooperative structures of interaction in a public school EFL classroom in Bogotá. Colombian Applied Linguistics Journal, 13(1), 20-34. https://doi. org/10.14483/22487085.2929

Perneth Parra, E. D. (2012). Identifying classroom activities to encourage oral participation among beginner level learners in an English class. Opening Writing Doors Journal, 9(1), 13-40.

Richards, J., \& Lockhart, C.W. (1994). Reflective Teaching in Second Language Classrooms. The Modern Language Journal, 79, 121.

Rosado-Mendinueta, N. (2012). Contingent interaction: A case study in a Colombia EFL classroom. Zona Próxima, 17, 154-175.

Soraya, A. (2017). Improving students' speaking skill through role play technique on eleventh grade students. Journal Pendidikan dan Pembelajaran Khatulistiwa, 6(11), 1-7.

Trong Tuan, L., \& Kim Nhu, N. T. (2010). Theoretical review on oral interaction in EFL classrooms. Studies in Literature and Language, 1(4-5), 29-48.

Van Lier, L. (1996). Interaction in the language curriculum: Awareness, autonomy, and authenticity. Longman.

Walsh, S. (2012). Classroom discourse and teacher development. Edinburgh University Press. http:/ /www. jstor.org/stable/10.3366/j.ctt1g0b484 